\title{
Penilaian Potensi Toksisitas Akut Dermal Obat Hewan Alami Minyak Rajas pada Tikus Wistar
}

\author{
(ASSESSMENT OF THE ACUTE DERMAL TOXICITY POTENTIAL OF NATURAL \\ VETERINARY MEDICINE MINYAK RAJAS IN WISTAR RATS)
}

\author{
I Made Merdana ${ }^{1 *}$, ST Kholifah Nor Azizati $^{2}$, Anak Agung Gde Arjana ${ }^{1}$, Anak Agung \\ Ayu Mirah Adi ${ }^{3}$, I Wayan Sudira ${ }^{1}$ \\ ${ }^{1}$ Laboratorium Fisiologi, Farmasi dan Farmakologi Veteriner, Fakultas Kedokteran Hewan, \\ Universitas Udayana, Jln. PB. Sudirman, Denpasar, Bali, Indonesia-80234; \\ ${ }^{2}$ Dokter Hewan Praktisi, Jl. Sunan Kalijaga RT. 002 RW. 001, Ngabar Siman, Ponorogo, \\ Indonesia-63471; \\ ${ }^{3}$ Laboratorium Patologi Veteriner, Fakultas Kedokteran Hewan, Universitas Udayana, Jln. \\ PB. Sudirman, Denpasar, Bali, Indonesia-80234. \\ *Email: imade_merdana@unud.ac.id
}

\begin{abstract}
Abstrak
Pengujian toksisitas terhadap suatu produk atau obat baru yang akan beredar dipasaran lazim dilakukan untuk mengetahui efikasi dan keamanannya. Penelitian ini bertujuan untuk menilai potensi toksisitas akut dermal obat hewan alami minyak rajas pada tikus wistar betina. Metode uji yang digunakan merujuk protokol Organization for Economic Co-operation and Development nomor tes 402 tahun 2017. Hasil uji diperoleh indeks iritasi primer sebesar nol, dan median lethal dose akut dermal $>2000 \mathrm{mg} / \mathrm{kgbb}$. Hal ini dapat disimpulkan bahwa minyak rajas tidak menimbulkan toksisitas akut dermal secara topikal dan aman untuk digunakan.
\end{abstract}

Kata kunci: obat hewan alami; minyak rajas; toksisitas akut dermal.

\begin{abstract}
Toxicity testing of a new product or drug that will circulate in the market is commonly done to determine its efficacy and safety. This study aims to assess the potential toxicity of the dermal acute natural veterinary medicine of Minyak Rajas on female Wistar rats. The test method used refers to the Organization for Economic Co-operation and Development protocol test number 402 of 2017. The test results obtained primary irritation index of zero, and the median acute dermal lethal dose $>2000 \mathrm{mg} / \mathrm{kg}$. It can be concluded that Minyak Rajas does not cause acute dermal toxicity topically and is safe for usage.
\end{abstract}

Keywords: natural veterinary medicine; minyak rajas; acute dermal toxicity.

\section{PENDAHULUAN}

Minyak Rajas merupakan obat hewan alami yang baru diproduksi oleh PT. Songgolangit Persada. Obat ini diramu secara khusus dari beberapa tanaman berkhasiat obat dengan teknologi Effective Microorganisme. Komposisi minyak rajas diantaranya simplisia rimpang kunyit 1,2\%, temulawak $1,2 \%$, jahe $1,1 \%$, lengkuas $1 \%$, bangle $1,1 \%$, alang-alang $0,4 \%$, daun sirih $0,7 \%$ dan minyak kelapa $76 \%$. Bahan herbal tersebut telah dilaporkan mengandung senyawa aktif dengan efek farmakologi, sebagai antioksidan, antiseptik, anti jamur, antiinflamasi, antibacterial, antipiretik, analgetik dan antiluka (Intahphuak et al., 2010; Kato et al., 2018; Anggraeni et al., 2019; Aaara et al., 2020). Minyak rajas secara organoleptik memiliki tekstur cairan agak kental (minyak), berwarna kuning kecoklatan, aroma khas bumbu (spice) herbal, dengan rasa pahit dan sedikit pedas. Formula herbal ini memiliki pH 5-6, dan density $923 \mathrm{mg} / \mathrm{ml}$. Obat hewan ini 
diindikasikan untuk meringankan penyakit kulit, peradangan kulit, obat luka baru/lama, gangguan pencernaan dan penyakit kecacingan pada hewan, serta penguat otot pada ayam aduan dan burung.

Pengujian toksisitas terhadap suatu produk atau obat baru yang akan beredar dipasaran lazim dilakukan untuk mengetahui efikasi dan keamanan serta potensi toksisitasnya. Selain itu uji kemanan diperlukan untuk memenuhi persyaratan atau perijinan edar suatu produk atau obat di masyarakat. Untuk keamanan penggunaan Minyak Rajas, maka diperlukan langkah lanjut pengumpulan data-data ilmiah mengenai potensi toksik pada hewan coba. Salah satu uji toksisitas yang umum dilakukan pada tahap awal yaitu uji toksisitas akut dermal (Anderson dan Meade, 2014). Uji ini bertujuan untuk mendeteksi efek toksik yang muncul dalam waktu singkat selama 14 hari setelah pemaparan tunggal bahan uji melalui rute dermal pada kulit hewan secara in vivo. Karakteristik bahan uji akan dinilai berdasarkan respon toksisitas yang muncul setelah pemaparan, juga indeks iritasi dan median lethal dose (LD50) akut dermal (Ali et al., 2013; Banerjee et al., 2013).

Pada studi ini penilaian potensi toksisitas akut dermal minyak rajas merujuk pada The OECD Guidline for Testing of Chemical - No. Test: 402, Acute Dermal Toxicity-Fixed Doses Procedure (OECD, 2017). Parameter uji meliputi penilaian klinis, perubahan berat badan, pengamatan makropatologi (makroskopis) dan kematian pada hewan uji. Pemilihan standard uji OECD dikarenakan diterima oleh banyak negara secara internasional untuk menguji keamanan suatu produk, kimia, kosmetik dan obat-obatan.

\section{METODE PENELITIAN}

\section{Lokasi penelitian dan Ethical Clearance}

Penelitian ini dilakukan di

Laboratorium Fisiologi, Farmasi dan Farmakologi Veteriner, Fakultas Kedokteran Hewan, Universitas Udayana, Bali, Indonesia. Seluruh prosedur pemakaian hewan coba telah mengikuti protokol dan mendapatkan persetujuan dari Komite Etik Hewan, Universitas Udayana, dengan surat persetujuan etik hewan nomor: 15/UN14.2.9/PT.01.04/2020.

\section{Rancangan percobaan}

Pengembangan model hewan coba pada penelitian ini merujuk pada The $O E C D$ Guidline for Testing of Chemical - No. Test: 402, Acute Dermal Toxicity - Fixed Doses Procedure. Parameter uji yang diamati meliputi penilaian klinis, perubahan berat badan, pemeriksaan makropatologi kulit, pemeriksaan patologi anatomi, dan kematian hewan uji (OECD, 2017). Pertimbangan pemilihan metode OECD dikarenakan optimalisasi desain penelitian dan menggunakan hewan uji yang lebih minimal. Selain itu, metode ini diterima secara internasional dan digunakan oleh peneliti di banyak negara.

\section{Hewan coba}

Penelitian ini menggunakan hewan uji tikus putih betina galur wistar. Tikus dalam keadaan sehat, umur 3-4 bulan dengan berat 200-250 gram, nulipara dan tidak bunting. Hewan diaklimatisasi selama satu minggu pada ruangan percobaan dalam kandang individual, dengan luas alas $300 \mathrm{~cm}^{2}$ dan tinggi $18 \mathrm{~cm}$ yang diberi alas sekam dengan kawat penutup. Suhu ruangan berkisar $25^{\circ} \mathrm{C}$, kelembaban $60-70 \%$ dan diberikan siklus pencahayaan 12 jam gelap/terang. Hewan diberi pakan pellet komersial standard laboratorium sebanyak 20 gram/ekor/hari dan disediakan air minum adlibitum, serta lingkungan yang minimum stress. Semua kandang dan hewan coba diberikan nomor dan dilakukan pengacakan sebelum perlakuan dimulai. Kondisi tersebut telah memenuhi kesejateraan hewan uji sesuai National Research Council (NRC, 2011).

\section{Persiapan hewan coba}

Sehari sebelum pengujian dilakukan pencukuran rambut pada area dorsal/flank seluas $6 \times 8 \mathrm{~cm}$ (sekurang-kurangnya $10 \%$ dari luas permukaan tubuh) untuk tempat pemaparan bahan uji. Pada proses 
pencukuran bulu hewan uji diberikan anestesi Ket-A-Xyl ${ }^{\circledR} \quad 0,1$ ml/ekor, dan dilakukan dengan hati-hati agar tidak menyebakan kerusakan/luka pada dermis. Hanya hewan dengan kulit yang sehat dan utuh digunakan dalam penelitian (OECD, 2017).

\section{Prosedur uji toksisitas akut dermal}

Tahapan uji toksisitas akut dermal diawali dengan uji pendahuluan dengan menggunakan satu ekor hewan coba langkah uji, seperti tahapan pada Gambar 1. Berdasarkan informasi bahan kimia uji yang diketahui, dosis awal yang berbeda dapat dipilih yaitu: 50, 200, 1000 atau 2000 $\mathrm{mg} / \mathrm{kgbb}$. Mengikuti prosedur uji utama akan ditetapkan dosis toksisitas akut dermal berdasarkan Globally Harmonized System (UN, 2015). Apabila tidak ada informasi mengenai kimia bahan uji, disarankan untuk memulai pengujian dengan dosis 200 $\mathrm{mg} / \mathrm{kgbb}$, dan bila terdapat cukup informasi dapat dimulai dengan dosis $1000 \mathrm{mg} / \mathrm{kgbb}$. Bahan kimia uji diaplikasikan pada kulit yang ditentukan, ditutup dengan kasa steril dan dibalut dengan plester yang tidak mengiritasi. Hal ini untuk menjamin bahan uji tetap kontak dengan kulit selama 24 jam dan tidak ada peluang bahan uji termakan oleh hewan. Pada akhir periode pemaparan, plester dibuka dan sisa bahan kimia uji yang masih melekat dibilas menggunakan aquadest atau pelarut netral lainnya. Observasi meliputi; penilaian klinis, pengamatan patologi serta kematian hewan pada jam ke-0, 24, 48, dan 72 setelah pemaparan bahan uji, dan pengamatan dilanjutkan sampai hari ke-14. Apabila hewan uji mengalami kematian atau gejala toksisitas parah, maka dilanjutkan dengan pengujian menggunakan dosis yang lebih rendah. Jika pada dosis uji terendah yang direkomendasikan menimbulkan kematian atau gejala toksisitas parah, maka pengujian dihentikan. Dosis tertinggi yang tidak menyebabkan kematian atau tidak menunjukkan gejala toksisitas parah akan digunakan pada uji utama toksisitas akut dermal. Semua hewan uji dan yang mengalami kematian atau dikorbankan dilakukan pemeriksaan makroskopik (Gambar 1).

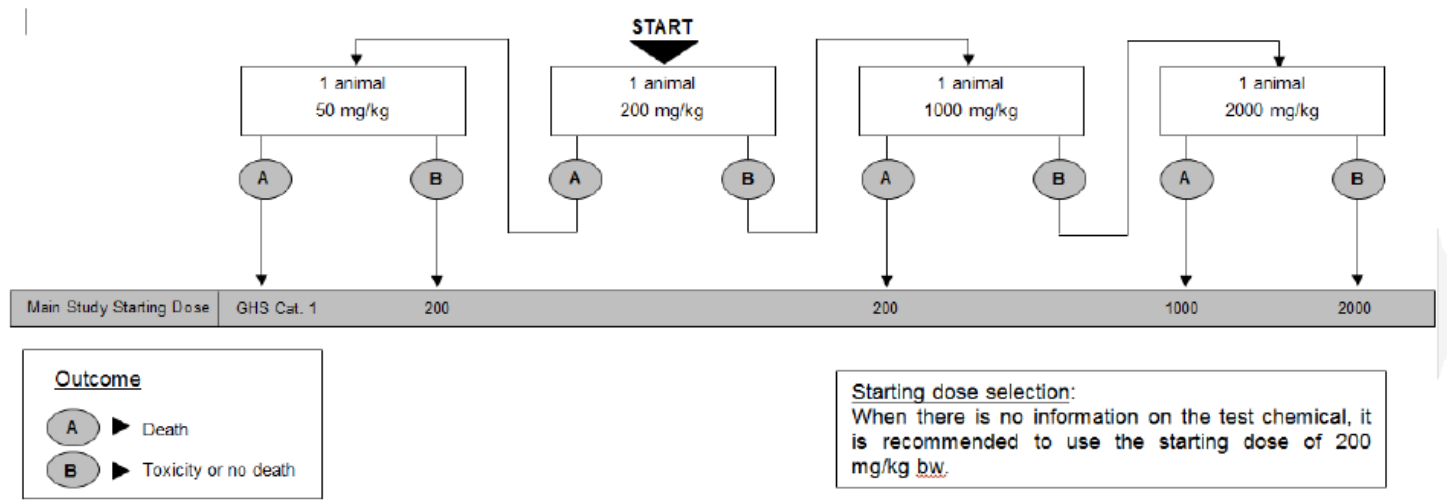

Gambar 1. Bagan alir uji pendahuluan toksisitas akut dermal (OECD, 2017)

Pada penelitian ini, telah dilakukan uji pendahuluan dengan dosis $1.000 \mathrm{mg} / \mathrm{kgbb}$. Pada semua interval pengamatan, tidak terjadi kematian dan tidak ditemukan respon klinis yang menunjukkan tandatanda toksisitas parah. Prosedur yang sama dilakukan menggunakan hewan uji yang baru dengan dosis $2.000 \mathrm{mg} / \mathrm{kgbb}$. Berdasarkan OECD (2017), dosis 2.000 $\mathrm{mg} / \mathrm{kgbb}$ merupakan dosis tertinggi yang direkomendasikan untuk konfirmasi uji toksisitas akut dermal, dengan penambahan 2 ekor hewan uji yang baru untuk setiap kelompok perlakuan dan kontrol. Pada uji ini, Minyak Rajas diaplikasikan dosis tunggal $2.000 \mathrm{mg} / \mathrm{kgbb}$ secara topikal, dan kelompok kontrol diberikan placebo dengan jumlah yang sama dengan 
perlakuan. Tahapan uji seperti pada Gambar 2.

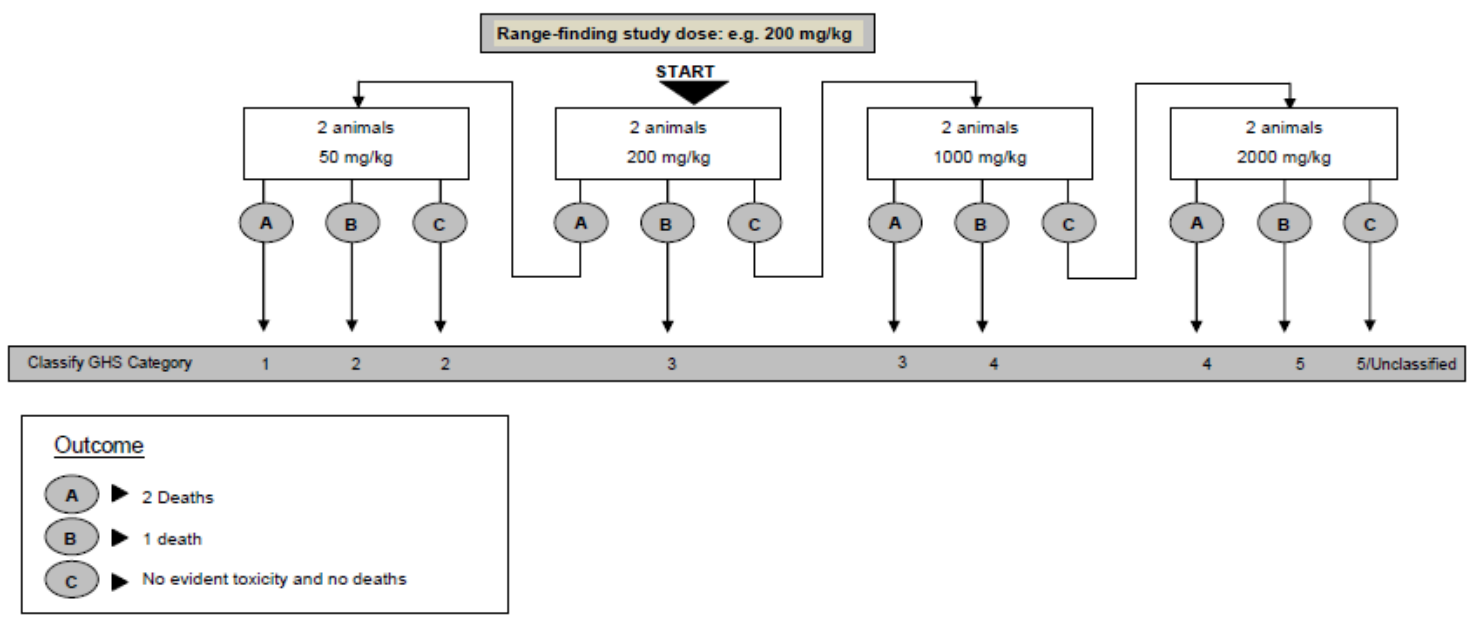

Gambar 2. Bagan alir uji toksisitas akut dermal (OECD, 2017)

\section{Pengamatan klinis}

Hewan dari kedua kelompok perlakuan diamati secara klinis segera setelah periode pemaparan. Perhatian khusus diberikan dengan pemeriksaan setiap jam pada 6 jam pertama dan dipantau selama 24 jam, dan selanjutnya pengamatan setiap hari sekali sampai hari ke-14. Dilakukan penimbangan berat badan tikus, pengamatan klinis secara visual, dan terhadap adanya kematian hewan uji. Semua timbulnya tanda-tanda toksik, waktu muncul, durasi toksisitas dan waktu pemulihan klinis, perubahan berat badan dan waktu kematian dicatat dengan sistematis, dan dibandingkan dengan kontrol. Perhatian khusus seperti pengamatan tremor, kejang, air liur, diare, lesu, tidur dan koma. Pengamatan harus mencakup perubahan pada kulit dan rambut, mata dan selaput mukosa, sistem pernapasan, peredaran darah, sistem saraf pusat dan otonom, aktivitas somatomotor dan perubahan pola perilaku. Penimbangan dilakukan pada saat sebelum diberi perlakuan, kemudian dilakukan setiap hari sampai akhir periode pengamatan. Hewan yang ditemukan dalam kondisi sekarat, menunjukkan rasa sakit parah atau tandatanda cidera fisik permanen harus segera dikorbankan.

\section{Pengamatan makroskopis}

Pengamatan makroskopis pada area kulit yang diberi perlakuan dilakukan pada 24, 48 dan 72 jam setelah perlakuan, terhadap munculnya respon iritasi seperti eritema dan edema. Penilaian berdasarkan Draize Test untuk menentukan tingkat iritasi kulit. Pada akhir periode pengamatan semua hewan uji dikurbankan dan dilakukan nekropsi untuk pemeriksaan patologi anatomi. Organ yang mengalami abnormalitas dilanjutkan dengan pemeriksaan histopatologi Setelah dilakukan pemeriksaan menyeluruh, seluruh sisa kadaver tikus dimusnahkan.

\section{Penilaian toksisitas akut dermal}

Penetapan LD50 sediaan uji berdasarkan Globally Harmonized System of Classification and Labelling of Chemicals (UN, 2015). Penilaian dan penetapan indeks iritasi berdasarkan Amanded Draize Test (OECD, 2017). Skoring menggunakan arbitrary scale yaitu tidak ada eritema: 0, eritema sangat ringan: 1, eritema terlihat jelas: 2 , eritema sedang sampai parah: 3 dan eritema parah: 4 . Tidak ada edema: 0, edema sangat ringan: 1, edema terlihat jelas: 2, edema tingkat sedang: 3 dan edema parah: 4. Klasifikasi indeks iritasi primer yaitu Tidak mengiritasi (Non-irritating): $\quad<0,5$; Iritasi ringan (Slightly irritating): 0,5-2,0; Iritasi sedang 
(Moderately irritating): 2,0-5,0; dan Iritasi parah (Highly irritating): 5,0-8,0 (Ali et al., 2013; Baldisserotto et al., 2018).

\section{Analisis data}

Data hasil pengamatan non-parametrik akan disajikan secara deskriptif. Semua data dinyatakan sebagai rerata $(\dot{\mathrm{x}} \pm \mathrm{SD})$. Analisis statistik nilai LD50 dilakukan menggunakan Thompson-Weil dengan interval kepercayaan $95 \%$. Perubahan berat badan sebelum dan sesudah perlakuan dianalisis dengan uji t berpasangan, dimana $\mathrm{p}<0,05$ dinyatakan signifikan. Indeks Iritasi Primer diklasifikasikan menurut amended Draize Test. Kesimpulan diambil berdasarkan analisis deskriptif dari analisis hasil masing-masing parameter.

\section{HASIL DAN PEMBAHASAN}

\section{Penilaian klinis}

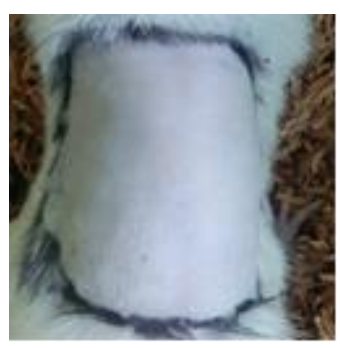

$$
\text { a.Placebo hari }
$$

ke-1

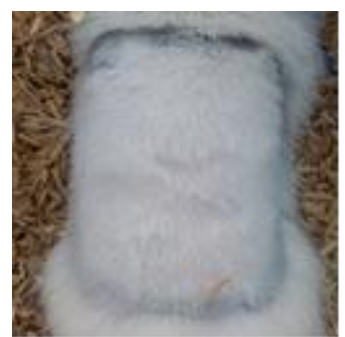

b. Placebo hari ke-14

Penilaian klinis meliputi pengamatan perubahan pola tingkah laku yang menunjukkan gejala toksisitas seperti penyimpangan aktivitas normal, gemetar, kejang, dan diare, pertumbuhan rambut serta jumlah dan waktu kematian jika ada hewan uji yang mati. Hasil pengamatan menunjukkan hewan coba pada 1-2 menit setelah diberikan paparan minyak rajas menjadi lebih aktif bergerak, dan setelahnya menunjukkan aktivitas normal sampai hari ke-14. Riversibilitas pertumbuhan rambut hewan uji mulai tampak pada hari ketiga, namun tidak merata pada semua hewan uji. Pertumbuhan rambut terlihat menutupi bagian tubuh yang dicukur mulai hari ke-9. Pada hari ke-14 pertumbuhan rambut tampak seperti sebelum perlakuan namun ukurannya yang masih lebih pendek dari kondisi semula. Pertumbuhan rambut pada perlakuan minyak rajas lebih cepat dibandingkan placebo (Gambar 3).

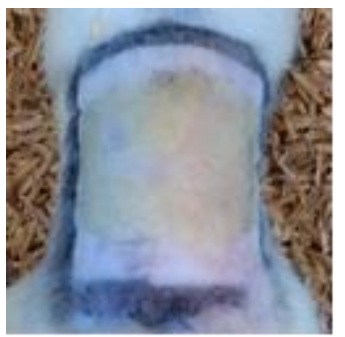

c. Bahan uji hari ke-1

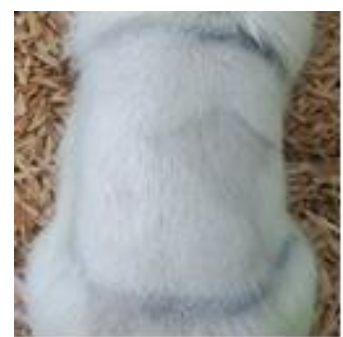

d. Bahan uji hari ke-14

Gambar 3. Reversibilitas pertumbuhan rambut hewan uji antara placebo dan perlakuan minyak rajas pada hari ke-1 dan hari ke-14.

\section{Pengamatan berat badan}

Penimbangan berat badan hewan uji sebelum dan sesudah perlakuan menggunakan timbangan skala 0,01 g. Data berat badan tikus disajikan pada Tabel 1 .

\section{Pengamatan makroskopis}

Pengamatan makroskopis kulit dilakukan secara visual pada 24, 48 dan 72 jam setelah pemaparan minyak rajas. Pada semua interval pengamatan tersebut tidak ditemukan lesi pada kulit seperti eritema dan edema, atau lesi kulit lainnya. Pada setiap pengamatan dilakukan penilaian, dan diberikan skor 0 (nol) pada parameter eritema dan edema, baik pada perlakuan maupun kontrol. Dokumentasi pengamatan makropatologi kulit ditampilkan pada Gambar 4 dan Tabel 2.

Kulit sebagai barier protektif memiliki fungsi vital untuk perlindungan tubuh dari pengaruh kondisi lingkungan luar, baik fisik, kimia dan biologi. Kulit juga berperan sebagai homeostatis, termoregulasi dan tempat sintesa vitamin D (Paul et al., 2011). Fungsi proteksi tersebut akan merespon setiap rangsangan ataupun gangguan yang terjadi pada kulit. Reaksi iritasi kulit positif ditandai dengan adanya respon eritema 
(kemerahan) dan atau edema pada daerah kulit yang terpapar (Irsan et al., 2013). Eritema merupakan kemerahan pada kulit maupun selaput lendir yang diakibatkan oleh hiperemia pada kapiler superfisial.
Edema merupakan lesi yang terjadi akibat adanya akumulasi cairan di dalam jaringan tubuh (Gatne et al., 2015; Berata et al., 2018).

Tabel 1. Bobot badan tikus sebelum dan sesudah uji toksisitas akut dermal

\begin{tabular}{cccccc}
\hline Kelompok & $\begin{array}{c}\text { Sebelum } \\
\text { uji }(\mathrm{g})\end{array}$ & $\begin{array}{c}\text { Rerata } \pm \text { SD } \\
(\mathrm{g})\end{array}$ & $\begin{array}{c}\text { Sesudah } \\
\mathrm{uji}(\mathrm{g})\end{array}$ & $\begin{array}{c}\text { Rerata } \pm \text { SD } \\
(\mathrm{g})\end{array}$ & $\begin{array}{c}\text { Perubahan } \\
\text { bobot }(\mathrm{g})\end{array}$ \\
\hline \multirow{3}{*}{ Placebo } & 205.96 & $208.06 \pm 2.86$ & 223.10 & $227.17 \pm 3.96$ & $19.11 \pm 1.76^{*}$ \\
& 211.32 & & 231.01 & & \\
& 206.89 & & 227.40 & & \\
\hline \multirow{2}{*}{ Minyak } & 202.39 & $201.14 \pm 1.17$ & 218.61 & $219.84 \pm 1.14$ & $18.70 \pm 2.15$ \\
Rajas & 200.06 & & 220.04 & & \\
& 200.98 & & 220.87 & & \\
\hline
\end{tabular}

Keterangan: *tidak berbeda nyata $(\mathrm{P}>0,05)$ bila dibandingkan dengan kelompok perlakuan Minyak Rajas

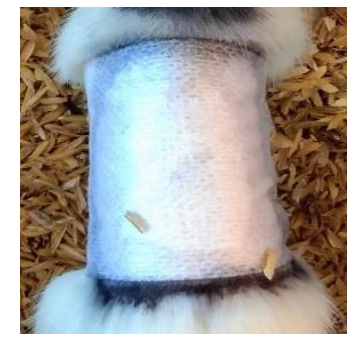

1. Placebo

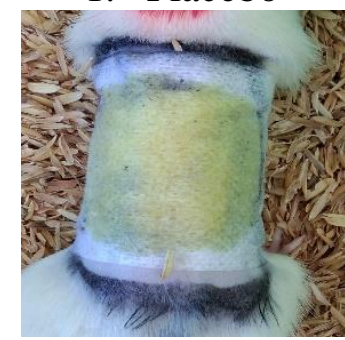

2. Minyak Rajas

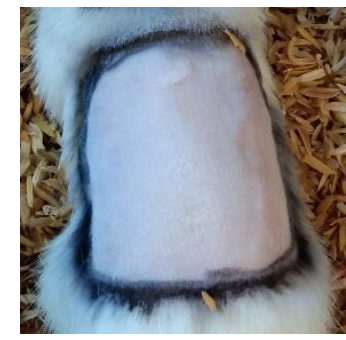

a. Jam ke-24

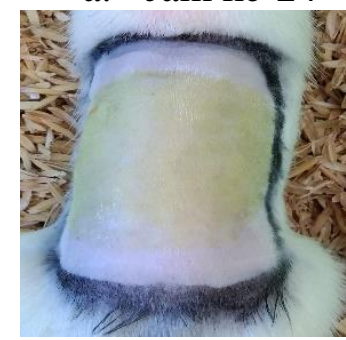

a. Jam ke-24

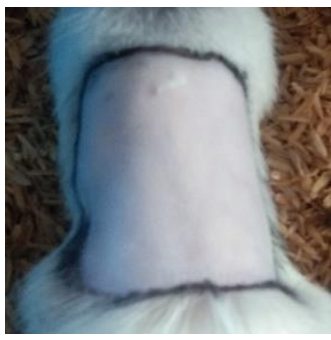

b. Jam ke-48

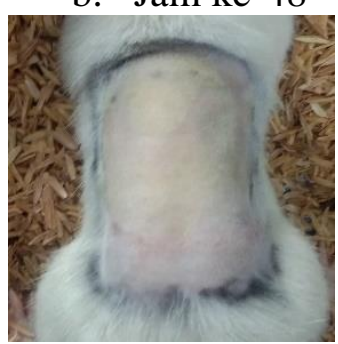

b. Jam ke-48

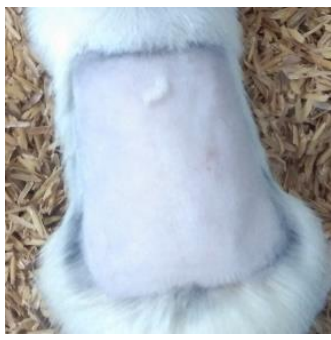

c. Jam ke-72

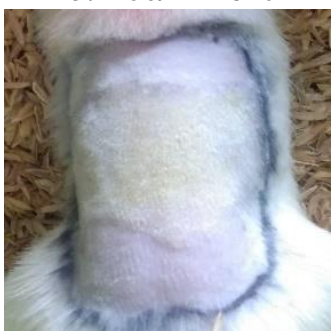

c. Jam ke-72

Gambar 4. Pengamatan makropatologi kulit setelah pemaparan Placebo dan Minyak Rajas dosis 2000 mg/kgbb selama 24 jam; a. pengamatan jam ke-24, b. jam ke-48; dan c. Jam ke- 72.

Tabel 2. Skoring Indeks Iritasi menurut Amanded Draize System

\begin{tabular}{|c|c|c|c|}
\hline \multirow{2}{*}{ Kelompok } & \multirow{2}{*}{ Hewan ke- } & \multicolumn{2}{|c|}{ Skor Iritasi } \\
\hline & & Eritema & Edema \\
\hline \multirow{3}{*}{ Placebo } & 1 & 0 & 0 \\
\hline & 2 & 0 & 0 \\
\hline & 3 & 0 & 0 \\
\hline \multirow{3}{*}{ Minyak rajas } & 1 & 0 & 0 \\
\hline & 2 & 0 & 0 \\
\hline & 3 & 0 & 0 \\
\hline \multicolumn{2}{|c|}{ Total skor (minyak rajas - placebo) } & 0 & 0 \\
\hline \multicolumn{2}{|c|}{ Rerata indek iritasi } & \multicolumn{2}{|c|}{$=0$} \\
\hline \multicolumn{2}{|c|}{ Hasil } & \multicolumn{2}{|c|}{$=$ Tidak mengiritasi } \\
\hline
\end{tabular}


Pengujian potensi toksisitas akut dermal minyak rajas dan lethal dosis akut dermal merujuk metode OECD, dikarenakan memiliki kelebihan dalam hal kemudahan metode uji, efisiensi penggunaan hewan coba dan kecepatan memperoleh hasil uji. Metode ini diterima secara global oleh banyak negara dan telah digunakan oleh banyak peneliti dalam pengujian produk, bahan kimia, kosmetik, dan obat-obatan (Ali et al., 2013; Banerjee et al., 2013; Gatne et al., 2015; Nyigo et al., 2015; Sasmito et al., 2015; Baldisserotto et al., 2018; Hakim et al., 2018). Pada studi ini, dosis $2000 \mathrm{mg} / \mathrm{kgbb}$ merupakan dosis tertinggi yang direkomendasikan sesuai protokol OEDC nomer test 402. Selama masa pengujian tidak ditemukan perubahan pola tingkah laku yang abnormal yang mencirikan tanda-tanda toksisitas, tidak terjadi perubahan berat badan yang mencirikan toksisitas sistemik, dan juga tidak muncul respon iritasi kulit yang positif, serta tercapai riversibilitas dilihat dari pertumbuhan rambut pada akhir periode pengamatan. Analisis hasil skoring eritema dan edema diperoleh indeks iritasi = 0, dan menurut klsifikasi Amanded Drize System dikategorikan sebagai nonirritating. Berdasarkan uraian diatas menurut Globally Harmonized System (UN, 2015) minyak rajas memiliki LD50 akut dermal >2000 mg/kgbb (OECD, 2017).

Minyak rajas diramu dari berbagai herbal yang berkhasiat obat, yaitu minyak kelapa, kunyit, temulawak, jahe, lengkuas, bangle, alang-alang, dan daun sirih. Indikasi minyak rajas secara topikal untuk meringankan berbagai infeksi pada kulit, peradangan kulit, obat luka/lama dan ditujukan untuk meningkatkan kekutan massa otot pada ayam aduan dan jenis burung lainnya. Penyakit kulit pada hewan umumnya disebabkan oleh bakteri, jamur, virus, dan karena faktor alergi (Amagai et $a l .$, 2017). Seringkali kejadian penyakit dikaitkan dengan kebersihan dan kesehatan lingkungan kandang. Begitu pula halnya dengan luka pada tubuh hewan, kesembuhan dapat berlangsung lama dan lesi bertambah parah apabila terjadi infeksi sekunder (Irsan et al., 2013; Berata et al., 2018). Efek farmakologis dari senyawa aktif yang terkandung pada berbagai tanaman herbal diatas, telah dilaporkan efektif secara invitro dan in vivo (Nevin dan Rajamohan, 2010; Salehi et al., 2019).

Metabolit sekunder pada Oleum cocos berperan sebagai antiinflamasi, antipiretik, analgetik dan antiluka (Intahphuak et al., 2010). Dari keluarga Zingiber sp. mengandung minyak atsiri, zingiberin, olericin, cineol, dengan aktivitas antiseptik, anti jamur, antiinflamasi, antibakterial, analgesik dan antioksidan (Praskas dan Pilerrod, 2010; Kato et al., 2018; Kaliyadasa dan Samarasinghe, 2019; Mao et al., 2019). Languatis rhizome mengandung bahan aktif etilsinamat dan quercetin sebagai antiinflamasi, antioksidan, antikanker dan antiaging (Amagai et al., 2017; Ahlina et al., 2020). Curcuma sp mengandung kurkuminoid dan minyak esensial (Vaughn et al., 2016; Ololade et al., 2020), sebagai antiseptik, analgesik, antijamur dan antiinflamasi (Shan et al., 2018; Ahmad et al., 2020). Imperatae rhizome mengandung alkaloid, flavonoid, fenolik, triterpennoid, glikosida tannin, saponin dan steroid sebagai antiinflamasi dan antiplatelet (Liu et al., 2010; Anggraeni et al., 2019). Piperis betle folium mengandung monoterpana, seskuiterpana dan eugenol sebagai antibakterial, antiparasit, antijamur dan antioksidan (Syahidah et al., 2017; Aaara et al., 2020).

Sebagai obat luka, minyak rajas mempercepat kesembuhan luka dengan meningkatkan proliferasi sel dan menstimulasi sintesis kolagen. Proliferasi kolagen penting dalam proses perbaikan jaringan, karena kolagen merupakan jaringan penghubung dermo-epidermal (dermo-epidermal junction) pada kultur keratinosit (Nevin dan Rajamohan, 2010; Zuhdan dan Nugroho, 2014; Vaughn et al., 2016). Pada luka lama yang mengalami infeksi sekunder, minyak rajas memiliki 
bahan aktif sebagai antiseptik, antibakteri dan anti jamur yang tentunya akan mengurangi keparahan infeksi (Anggraeni et al., 2019; Mao et al., 2019; Aaara et al., 2020). Kombinasi berbagai bahan aktif pada sediaan obat hewan alami minyak rajas, diharapkan menghasilkan efek farmakologis yang sinergis untuk pengobatan dan aman digunakan untuk hewan. Hasil yang sama diungkapkan pada uji poliherbal gel mastilep yang mengandung ekstrak Cedrus deodara, Curcuma longa, Glycyrrhiza glabra dan Eucalyptus globulus (Gatne et al., 2015), dan juga sediaan topikal cream Moringa oleifera (Ali et al., 2013; Baldisserotto et al., 2018).

\section{SIMPULAN DAN SARAN}

\section{Simpulan}

Telah dilakukan uji toksisitas akut dermal sediaan obat hewan alami Minyak Rajas dengan protokol OECD pada tikus wistar betina dengan hasil indeks iritasi $=0$, dan LD50 akut dermal >2000 mg/kgbb. Hal ini dapat disimpulkan bahwa obat hewan alami Minyak Rajas tidak menyebabkan toksisitas akut dermal pada pemakaian secara topikal dan aman untuk digunakan.

\section{Saran}

Dengan diketahuinya fakta ilmiah pendukung mengenai karakteristik bahan uji dan LD50 akut dermal dari Minyak Rajas maka disarankan untuk dilakukan uji toksisitas sub kronik dan kronik.

\section{UCAPAN TERIMAKASIH}

Para penulis mengucapkan terimakasih kepada PT. Songgolangit Persada, Bali dan Fakultas Kedokteran Hewan Universitas Udayana, Bali, yang telah menyediakan fasilitas, petunjuk dan dukungan yang diperlukan dalam penelitian ini.

\section{DAFTAR PUSTAKA}

Aara A, Chappidi V, Ramadas MN. 2020. Antioxidant activity of eugenol in piper betel leaf extract. J. Family Med. Prim. Care., 9(1): 327-331.
Ahlina FN, Nugraheni N, Salsabila IA, Haryanti S, Da'i M, Meiyanto E. 2020. Revealing the reversal effect of galangal (Alpinia galanga L.) extract against oxidative stress in metastatic breast cancer cells and normal fibroblast cells intended as a CoChemotherapeutic and anti-ageing agent. Asian Pac. J. Cancer Prev., 21(1): 107-117.

Ahmad RS, Hussain MB, Sultan MT, Arshad MS, Waheed M, Shariati MA. 2020. Biochemistry, safety, pharmacological activities, and clinical applications of turmeric: a mechanistic review. eCAM, 2020(7656919):14.

Ali A, Akhtar N, Mumtaz AM, Khan MS, Iqbal FM, Zaidi SS. 2013, In vivo skin irritation potential of cream containing Moringa oliefera leaf extract. African J. Pharm. Pharmacol., 7: 289-293.

Amagai Y, Katsuta C, Nomura Y, Oida K, Matsuda K, Jang H, Ahn G, Hamasaki T, Matsuda H, Tanaka A. 2017. Amelioration of atopic-like skin conditions in NC/Tnd mice by topical application with distilled Alpinia intermedia Gagnep extracts. J. Dermatol., 44(11): 1238-1247.

Anderson SE, Meade BJ. 2014. Potential health effects associated with dermal exposure to occupational chemicals. Environ. Health Insights, (8): 51-62.

Anggraeni N, Syamsunarno MRA, Widyastuti R, Puspitasari IM, Praptama S. 2019. Potential dual effect antiinflammatory and anti-platelet of cogon grass ethanol extract on diabetic mice a preliminary study. IOP Conf. Series: J. Physics. 1246: 012006.

Baldisserotto A, Buso P, Radice M, Dissette V, Lampronti I, Gambari R, Manfredini S, Vertuani S. 2018. Moringa oleifera leaf extracts as multifunctional ingredients for natural and organic sunscreens and photoprotective preparations. Molecules, 23:664.

Banerjee S, Chattopadhyay P, Ghosh A, Pathak MP, Singh S, Veer V. 2013. 
Acute dermal irritation, sensitization, and acute toxicity studies of a transdermal patch for prophylaxis against anatoxin-a poisoning. Int. J. Toxicol., 32(4): 308-313.

Berata IK, Winaya IBO, Adi AAAM, Adyana IBW. 2018. Patologi Veteriner Umum. Swasta Nulus. Denpasar.

Gatne MM, Tambe K, Adarsh, Ravikanth K. 2015. Acute dermal irritation study of polyherbal gel mastilep in rabbits. Int. J. Pharm. Sci. Res., 6(8): 34733476.

Hakim ZR, Purbarini KA, Tjiptasurasa. 2018. Uji iritasi akut dermal pada hewan uji kelinci albino terhadap sediaan body lotion ekstrak kulit biji pinang (Areca Catechu L.). Farmaka, 18(1): 1-13.

Intahphuak S, Khonsung $\mathrm{P}$, Panthong $\mathrm{A}$. 2010. Anti-inflammatory, analgesic, and antipyretic activities of virgin coconut oil. Pharm. Biol., 48(2): 151157.

Irsan MA, Manggau E, Pakki, Usmar. 2013. Uji iritasi krim antioksidan ekstrak biji lengkeng (Euphoria longana Stend) pada kulit kelinci (Oryctolagus cuniculus). Majalah Farm. Farmakog., 17(2): 55-56.

Kato E, Kubo M, Okamoto Y, Matsunaga Y, Kyo H, Suzuki N, Uebaba K, Fukuyama Y. 2018. Safety assessment of bangle (Zingiber purpureum Rosc.) rhizome extract: acute and chronic studies in rats and clinical studies in human. ACS Omega., 3(11): 1587915889.

Kaliyadasa E, Samarasinghe BA. 2019. Genus alpinia, a potential power house of bioactives: a review. Int. J. Pharm. Sci. Res., 10(6): 2644-2653.

Liu RH, Fu LN, Chen LY, Ren G., Chen SS, Chen Z. 2010. Chemical constituents and pharmacology study of Imperata cylindrical rhizomes. $J$. Tradit. Chin. Med., 22(4): 80-83.

Mao QQ, Xu XY, Cao SY, Gan RY, Corke H, Beta T, Li HB. 2019. Bioactive compounds and bioactivities of ginger
(Zingiber officinale Roscoe). Foods, 8(6):185.

Nevin KG, Rajamohan T. 2010. Effect of topical application of virgin coconut oil on skin components and antioxidant status during dermal wound healing in young rats. Skin Pharmacol. Physiol., 23(6): 290-297.

NRC. 2011. Guide for the Care and Use of Laboratory Animals. $8^{\text {th }}$ Ed. National Research Council (US). Washington, D.C. The National Academies Press.

Nyigo VA, Mdegela R, Mabiki F, Malebo HM. 2015. Assessment of dermal irritation and acute toxicity potential of extracts from synadenium glaucescens on healthy rabbits, wistar albino rats and albino mice. European J. Med. Plants, 10(4): 1-11.

OECD. 2017. OECD Guidline For The Testing Of Chemicals 402: Acute Dermal Toxicity-Fixed Dose Procedure. Paris.

Ololade ZS, Abam EO, Anuoluwa IA, Abiona OO. 2020. Secondary metabolites, pharmacognostic and therapeutic activities of the rhizome extract of Curcuma longa grown in South-West, Nigeria. $J$. Phytopharmacol., 9(1): 30-37.

Paul AJ, Ann M, Goodwin C. 2011. Anatomy and Physiology of the Skin. $J$. Dermatol. Nurses' Assoc., 3: 203-213.

Praskash J, Pilerood SA. 2010. Chemical composition and antioxidant properties of ginger root (Zingiber officinale). $J$. Med. Plants Res., 4(24): 2674-2679.

Salehi B, Zakaria ZA, Gyawali R, Ibrahim SA, Rajkovic J, Shinwari ZK, Khan T, Sharifi-Rad J, Ozleyen A, Turkdonmez E, Valussi M, Tumer TB, Fidalgo LM, Martorell M, Setzer WN. 2019. Piper species: a comprehensive review on their phytochemistry, biological activities and applications. Molecules. 24(7): 1364.

Sari AM, Cikta EV. 2016. Ekstraksi flavonoid dari temu ireng (Curcuma Aeruginosa Roxb) dan aplikasinya pada 
sabun transparan. J. Konversi., 5(1): 17-23.

Sasmito WA, Wijayanti AD, Fitriana I, Sari PW. 2015. The acute toxicity test of herbal medicine in mice based on Organization for Economic Cooperation and Development (OECD). $J$. Sains Vet., 33(2): 234-239.

Shan CY, Iskandar Y. 2018. Studi kandungan kimia dan aktivitas farmakologi tanaman kunyit (Curcuma longa L.). Farmaka, 16(2): 547-554.

Syahidah A, Saad CR, Hassan MD, Rukayadi Y, Norazian MH, Kamarudin MS. 2017. Phytochemical analysis, identification and quantification of antibacterial active compounds in betel leaves, piper betle methanolic extract. Pakistan J. Biolog. Sci. 20: 70-81.

UN. 2015. Globally Harmonized System of Classification and Labelling of Chemicals (GHS). Fifth Revised Edition, United Nation, New York and Geneva.

Vaughn AR, Branum A, Sivamani RK. 2016. Effects of turmeric (Curcuma longa) on skin health: a systematic review of the clinical evidence. Phytother. Res. 30(8): 1243-1264. 